Relations industrielles

Industrial Relations

\title{
Dubé Jean-Louis et Nicola D'Iorio. Les normes du travail
}

\section{Fernand Morin}

Volume 48, numéro 3, 1993

URI : https://id.erudit.org/iderudit/050885ar

DOI : https://doi.org/10.7202/050885ar

Aller au sommaire du numéro

Éditeur(s)

Département des relations industrielles de l'Université Laval

ISSN

0034-379X (imprimé)

1703-8138 (numérique)

Découvrir la revue

Citer ce compte rendu

Morin, F. (1993). Compte rendu de [Dubé Jean-Louis et Nicola D'Iorio. Les normes du travail]. Relations industrielles / Industrial Relations, 48(3), 585-587. https://doi.org/10.7202/050885ar

Tous droits réservés (C) Département des relations industrielles de l'Université Laval, 1993
Ce document est protégé par la loi sur le droit d'auteur. L’utilisation des services d'Érudit (y compris la reproduction) est assujettie à sa politique d'utilisation que vous pouvez consulter en ligne.

https://apropos.erudit.org/fr/usagers/politique-dutilisation/ 
seulement fait mention de l'existence au Québec, en Nouvelle-Écosse et dans l'ordre fédéral de l'arbitrage légal relatif au congédiement injuste.)

Ces courtes synthèses diffèrent quelque peu formellement entre elles. Ainsi, le texte américain, qui doit également faire état d'une semblable dualité de régime, insiste sur le développement historique de dérogations législatives et jurisprudentielles au employment at will. On y trouve également une comparaison de la notion traditionnelle de « cause juste » - issue du contrat a durée déterminée - et de son acception moderne. La synthèse allemande, toujours à titre illustratif, ne peut manquer de faire état des rôles respectifs de la négociation collective et des institutions de codétermination; elle traite également des tribunaux du travail et insiste sur les modes de sanction des obligations du salarié. Le rapport italien présente de façon liminaire la conception du pouvoir disciplinaire entretenue par le droit de ce pays au fil de son histoire et met en relief l'importance du rôle actuel de la convention collective. Le professeur Rojot, non seulement présente-t-il, malgré sa relative complexité, les aspects saillants du système français et des lois, notamment de 1973 et de 1982, qui l'ont façonné, mais s'interroge également sur le fondement, institutionnel ou contractuel, du pouvoir de direction de l'employeur, réflexion dont on aimerait connaître le pendant, dans la mesure où il peut exister, dans d'autres pays.

Tout cela cependant risque de distraire de ce qui, encore une fois, constitue la dimension caractéristique de la démarche : les analyses situationnelles concrètes. Leur résultat est évidemment tributaire des paramètres juridiques applicables. Or, ceux-ci diffèrent fondamentalement à l'occasion, par exemple relativement à l'incitation à la grève: liberté fondamentale, non généralement réglementée (France, Italie); illégalité, au contraire, d'un tel comportement en cours de convention collective : Canada (obligation légale de paix), États-Unis (obligation conventionnelle); Allemagne ... Malgré tout, la conclusion générale, tout en signalant des disparités d'intensité de différents devoirs se rattachant au statut de salarié, retient néanmoins un dénominateur commun significatif à travers les différentes manifestations nationales de ce statut. Ne procède-t-il pas toujours, quelle que soit la nature du système juridique en cause, d'une situation de subordination?

Pierre Verge

Université Laval

Les normes du travail, $2^{\circ}$ éd., par Jean-Louis Dubé et Nicola D'lorio, Les Éditions Revue de Droit, Université de Sherbrooke, 1992, 779 p., ISBN 2-920003-17-8

Cinq ans après la parution de la première édition de cet ouvrage, ses mêmes auteurs nous offrent une autre version qui se veut une mise à jour, notamment pour prendre en compte les modifications apportées à la Loi sur les normes du travail en 1990 (L.Q. 1990, c. 73) et l'évolution de la jurisprudence. En raison de nombreux points communs entre ces deux publications (le même énoncé principal de la loi, le même plan et les mêmes auteurs), il y a lieu de référer le lecteur à notre recension initiale $(1987,42$ Relations industrielles 655) pour éviter quelques redites ou doublons. 
On comprend que les auteurs aient voulu traiter, en tout premier lieu, des deux personnes les plus directement visées soit le salarié et l'employeur (p. 15 à 62). À ces fins, on utilise, à la faveur du pot nous semble-t-il, des décisions du Tribunal du travail, des arbitres de grief et des tribunaux judiciaires. Sous le titre prometteur de "Réconciliation de différentes conceptions » relatives à la définition du salarié (p. 33 à 41), il nous fut néanmoins difficile d'y retrouver l'harmonisation ainsi annoncée. Il nous surprend que l'on ait pas évoqué à cette fin les définitions retenues au nouveau code civil au sujet du contrat de travail et du contrat d'entreprise (les articles 2085, 2098 et 2099) et qui devraient incessamment s'appliquer. Ce droit commun nouvellement codifié distingue le contrat de travail du contrat de service à l'aide de la subordination juridique que l'on doit retrouver dans l'un et, nullement dans l'autre. On nous réfère à ce nouveau code civil au sujet du maintien du contrat de travail suite à une succession d'employeurs (art. 2097) et alors, d'une façon fort sibylline (p. 288).

Messieurs Dubé et D'lorio traitent abondamment des modifications de 1990 apportées à cette loi, mais d'une manière très narrative. Si on souligne les changements apportés aux articles 82 et 83 (avis de cessation d'emploi), on le fait sans rendre compte des raisons susceptibles d'expliquer ces changements et sans discuter de l'application qu'en avaient faite certains tribunaux (p. 154 et s.). Ce même constat vaut également au sujet de leur exposé des modifications apportées aux recours aménagés aux articles 122 et 124 (p. 289 et 394). Puisque ces auteurs disposaient de la documentation de la Commission des normes du travail (leur aveu à l'avant-propos), il aurait été utile qu'ils discutent du procès de l'application de ces mêmes dispositions au cours de la décennie précédente et des motifs avancés pour justifier le choix des moyens nouveaux retenus et qu'ils complètent le tout d'une critique bien étayée.

La Loi sur les normes du travail reconnaît au gouvernement un vaste pouvoir de réglementation, ce qui confère à cet acte une grande élasticité ou rétractilité. Malgré cette caractéristique importante au niveau politique et juridique, l'exposé de cette question est contenu en deux pages (p. 237 à 239). Dans la même veine, on aurait pu éviter d'élever au rang de chapitres VI et VII les énoncés relatifs à la faillite et aux infractions (p. 603 à 606) alors que l'on consacrait 312 pages au chapitre V (les recours). En somme, on suivit de trop près le plan du légiste et la lettre de la loi, ce qui se traduit par une disproportion des parties et exposés de l'ouvrage.

En ce deuxième essai, alors qu'il était possible de prendre un certain recul, d'embrasser des grands ensembles, de peaufiner l'énoncé initial, d'évaluer la portée pratique et judiciaire des dispositions principales, de ne retenir que les décisions à effets d'entraînement certains, les auteurs ont préféré ne pas se compromettre et refusèrent de faire des choix. En plus, on y retrouve parfois des énoncés bizarres, antinomiques ou tautologiques. $\AA$ titre d'exemples, nous en rappelons trois :

— «Le droit de ne pas être congédié » (p. 346);

— La démission définie comme «... le fait pour un salarié de quitter son emploi dans l'intention de quitter son emploi » (p. 481);

— «Traitements pratiques divers accordés à certaines questions » (p. 520).

En somme, nous devrons attendre une troisième édition qui constituerait une véritable analyse critique de la Loi sur les normes du travail. Cet instrument serait utile et 
même nécessaire parce qu'il s'agit de la loi du travail la plus fondamentale, qui sert à la fois de protection minimale pour tous les salariés laissés seuls devant leur employeur et pour les autres, de seuil de départ à la négociation collective du travail.

Université Laval

Fernand Morin

The Union and its Members: A Psychological Approach, by Julian Barling, Clive Fullagar, and E. Kevin Kelloway, New York, Oxford University Press, 1992, 251 p., ISBN 0-19-507336-3

Over the past decade there has been a resurgence of interest in labor unions and their members among behavioral scientists. This volume is an important addition to the burgeoning research literature of the field, not because it presents new findings or settles debates over conceptual issues but rather because it is the first to thoroughly and systematically appraise the state of the art. The authors make a major contribution by emphasizing the research questions that remain unanswered and repeatedly demonstrating how industrial relations scholars and psychologists can work together for mutual gain.

The authors' objective is to "apply the knowledge base of organizational psychology to an understanding of the unionization process'" (p. v). Rather than just assuming that unionization means union organizing, the term is properly defined to include the employees' selection of the union as bargaining agent, participation in union activities, commitment to the union, and the decision to leave the union or terminate its bargaining status.

The book is divided into seven review chapters and brief introductory and concluding chapters. One chapter traces the impact of union structural characteristics, for example union size and degree of centralization, on membership participation, effectiveness in collective bargaining, and members' attitudes. Another chapter thoroughly reviews research findings about macro- and micro-level predictors of union support in certification elections. Conclusions are reached, for example, about the importance of perceived union instrumentality and job dissatisfaction in the workers' decision to vote for union representation.

The fourth and fifth chapters deal with union commitment and participation. These are the most thorough and insightful discussions, a reflection of the authors' considerable expertise in the areas. Much of the rigorous research on union commitment has been produced over the last dozen years and the new and unsettled nature of the field understandably leads the authors to reach tentative conclusions. While union participation has been studied in depth for a longer time, the authors nonetheless demonstrate that crucial questions about components, causes and outcomes of participation have yet to be adequately addressed.

A chapter on leadership is unfortunately restricted to the case of the shop steward. This seems logical - the shop steward is the rank-and-file leader and occupies the first step on the ladder to the higher local and national positions. But the narrow perspective of the chapter results in a review of primarily British research, the main body of work 